\title{
Transshipment hub port selection criteria by shipping lines: the case of hub ports around the bay of Bengal
}

\author{
Chathumi Kavirathna ${ }^{1 *}$, Tomoya Kawasaki ${ }^{2}$, Shinya Hanaoka ${ }^{3}$ and Takuma Matsuda ${ }^{4}$
}

\author{
* Correspondence: chathumi.k.aa@ \\ m.titech.ac.jp \\ ${ }^{1}$ Department of Transdisciplinary \\ Science and Engineering, Tokyo \\ Institute of Technology, Tokyo, \\ Japan \\ Full list of author information is \\ available at the end of the article
}

\begin{abstract}
With the competitive nature of the liner shipping industry, the transshipment hub port selection process has become complicated with numerous decision-making criteria that need to be considered, and competition between hub ports has accelerated across different regions. The emergence of different liner service networks, such as "hub and spoke" and "relay," has also intensified the complexity of the hub port selection process. The overlapping of maritime markets simultaneously served by multiple competitive hub ports has offered various hub port choices for shipping lines. Therefore, the criteria for hub port selection for both hub and spoke and relay networks are separately discussed in this study, which evaluates the performances of four competitive hub ports located around the Bay of Bengal: Colombo, Singapore, Kelang, and Tanjung Pelepas. The hub port selection criteria are evaluated based on the monetary, time, port traffic, location, operation, and liner-related categories using a questionnaire survey administered to shipping lines. The results provide a detailed discussion on the significant criteria for both network types and also highlight the dominant performance of the Singapore port and the performance of the other hub ports based on the individual criteria.
\end{abstract}

Keywords: Transshipment, Hub and spoke, Relay, Competitiveness, Selection criteria, Shipping lines

\section{Introduction}

Freight volumes via maritime transport have grown considerably given the rapid development in international trade and globalization. The liner shipping industry became complicated due to the involvement of multiple players with strategic alliances and the cascade effect supported by vessel size increases. As explained by Ducruet and Notteboom (2012), various forms of liner shipping network structures, such as "hub and spoke" and "relay," came into practice for optimizing service coverage.

Transshipment refers to the shipment of goods/containers to an intermediate destination before being taken to the final destination (Soamiely et al. 2004) and plays a critical role due to infrastructure limitations in minor sea ports and shipping lines' strategies of limiting ports of call. According to Ducruet and Notteboom (2012), on average, a container was handled 3.5 times between the first port of loading and the final port of discharge in 2008, which implies the significance of transshipment

(c) The Author(s). 2018 Open Access This article is distributed under the terms of the Creative Commons Attribution 4.0 International License (http://creativecommons.org/licenses/by/4.0/), which permits unrestricted use, distribution, and reproduction in any medium, provided you give appropriate credit to the original author(s) and the source, provide a link to the Creative Commons license, and indicate if changes were made. 
operations and that container transshipment volume has grown continuously with vessel enlargements. As per Notteboom et al. (2014), 28\% of world container port throughput was represented by transshipment cargo in 2012, which implies incremental growth of 383.2\% since 1995.

Given the current nature of the liner shipping industry, the transshipment hub port selection process has become more complicated. Albert and Olli-Pekka's (2012) analysis of the future transshipment status of Singapore port emphasizes the continuous changes in the competitive landscape and the leading actors in the liner shipping industry. The progress of secondary ports over their major competitors is described by Ducruet et al. (2011), who emphasize that the overall network structure tends to remain polarized by a few major hub ports that are resisting internal and external threats. As per Gohomene et al. (2016), the port selection decision could vary across geographic regions, as the port choice results in Africa are significantly different from those in other regions, such as Asia, North America, and Europe. The authors also show that, in West Africa, a larger market size does not guarantee that a port will be more attractive. Dyck and Ismael (2015) state that, from the perspective of shipping lines, the transshipment hub port selection decision has become more complicated due to the competitive offerings provided by multiple ports simultaneously. Therefore, an increasing number of competitive hub ports in neighboring regions have promoted the hubhopping nature of the liner shipping industry (Koi 2006). Furthermore, the academic literature often highlights the substantial vulnerability of the positions of pure transshipment hubs with high dynamicity in the transshipment market, as transshipment cargo can easily be moved to new emerging hubs (Notteboom et al. 2014). As Minju et al. (2011) discuss, incidents such as Maersk Sealand's relocation of its major transshipment operations from Singapore to Tanjung Pelepas have induced similar changes by other shipping lines as well, which negatively affects the competitiveness of Singapore.

The roles of transshipment hub ports could vary depending on the liner network type, such as hub and spoke or relay. Notteboom et al. (2014) classify the markets served by major European ports such that some hub ports play significant roles in hub and spoke networks and some are mainly devoted to relay/interlining operations. However, several previous studies on port choice/competition analysis do not focus on transshipment hub port selection criteria related to different forms of liner service networks. Although most of these studies analyze hub port selection criteria, none attempt to develop an integrated framework of the major influencing factors on hub port selection from a practical viewpoint to understand the relationships among these factors. Moreover, most studies consider only a limited number of selection criteria and confine their scope to competitiveness among neighboring hub ports.

As its significant contribution, this study emphasizes the hub port selection criteria for two types of liner networks, the hub and spoke and relay networks, as illustrated by Ducruet and Notteboom (2012), and considers the natures of the individual networks (e.g., criteria related to feeder links are expected to be especially significant for hub and spoke networks). A hub and spoke network is characterized by combining the advantages of both mainline and feeder services, which are operated in an integrated manner by incorporating network configuration to ensure transportation between the ultimate origin and destination ports. A relay network is an integration of multiple mainline 
services to enhance service coverage with the minimum ports of call. Transshipment operations in relay networks are undertaken between two mainline vessels with different ports of call patterns when one vessel receives cargo destined for a port not directly served by the vessel. Hub and spoke and relay networks are illustrated in Fig. 1.

As per Fig. 1, in hub and spoke networks, shipping lines can accept cargo destined to different feeder markets not directly served by mainline vessels. Furthermore, these networks create economies of scale advantages for mainline services by deploying larger capacity vessels for the network's trunk route. Due to the enlargement of container vessel sizes and the infrastructure limitations in minor ports, hub and spoke networks are extensively used in the liner business (Ducruet and Notteboom 2012). With relay networks, shipping lines can maintain the minimum number of ports of call without limiting service coverage. However, due to the involvements of two mainline vessels and the absence of a feeder segment, the shipping line's expectations of hub ports in relay networks could differ from those of hub and spoke networks.

Due to their location characteristics and operational performances, four hub ports, namely, Colombo in South Asia and Singapore, Kelang, and Tanjung Pelepas in Southeast Asia, compete in the feeder market related to the Bay of Bengal, which is not directly served by mainline vessels in hub and spoke networks. Moreover, due to their close proximity to the East-West trunk sea route, these four hub ports compete with each other to be selected as the transshipment hub for relay networks. The consideration of two liner networks is important, as shipping lines take this aspect into account when determining the movement of containers. As an example, if one vessel has containers destined to Tuticorin feeder port as well as containers being transshipped to another mainline vessel, and if this first vessel calls at both Colombo and Singapore, the container destined to Tuticorin port would be transshipped at Colombo because of the lower feeder cost, whereas the container being transshipped to another mainline vessel would be transshipped at Singapore because the connecting mainline vessel also calls at Singapore port. We assume that these aspects create distinct roles for transshipment hubs in hub and spoke or relay networks.

Considering the clear research gap in the previous literature and the competitive scenario among hub ports serving the Bay of Bengal, the objectives of this study are to develop a contextualized framework of the factors influencing hub port selection from the practical viewpoint of shipping lines; to identify significant criteria for transshipment hub port selection considering hub and spoke, and relay networks separately; and

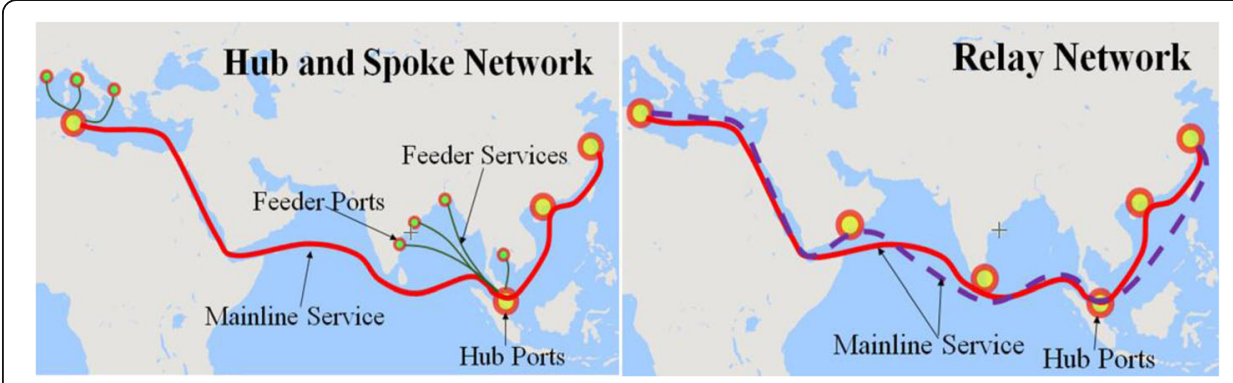

Fig. 1 Hub and Spoke and Relay Networks. Source: Created by the author based on Ducruet and Notteboom (2012) 
to evaluate the competitiveness of the four selected hub ports around the Bay of Bengal by developing a port performance index.

The remainder of this paper is organized as follows. Section 2 reviews the relevant literature, and Section 3 introduces the focus study area and explains the methodology. The results and discussions are presented in Section 4. Finally, Section 5 summarizes the study.

\section{Literature review}

Port selection criteria are extensively reviewed in previous studies considering both hub port selection by shipping lines and port selection by shipping lines, forwarders, and shippers in general.

Regarding hub port selection, Kurt et al. (2015) perform an analysis considering the Mediterranean Sea and indicate the location as the key factor, with proximity to main routes, cities, and ports; liner shipping connectivity; operation performance; sufficient capacity; and investment to develop infrastructure as important sub-factors. Lirn et al. (2003) analyze the transshipment decision-making behavior of Taiwanese carriers, for which cost, port management, geographical location, and physical characteristics are considered to be the main criteria. Veldman and Buckmann (2003) study the competition among West European hub ports, considering cost, transit time, frequency, and indicators of service quality as the explanatory variables. Koi's (2006) study of hub port competition in Europe suggests that money and time are not sufficient to explain the choices of shipping lines, whereas other less quantifiable factors, such as geography, quality of services, values and perceptions, inertia, and limitations of liners are significant. Wang (2011) reveals that port location, feeder services and intermodal connections, the size of the hinterland, and port efficiency are important hub port selection criteria in Europe. Furthermore, hub port choice in East Asia is analyzed by Tai and Hwang (2005), who emphasize the handling efficiencies and drafts of harbor as the main internal factors and the hinterland cargo sources and route frequencies as the main external factors of ports. They also highlight operating cost savings as a primary factor for shipping lines.

For studies related to port selection in general, different perspectives have been considered. From the perspective of shipping lines, Lirn and Beynon (2006) determine the port selection criteria for Nigerian ports, emphasizing efficiency, frequency of ship visits, adequate infrastructure, and quick responses to port users' needs as significant criteria. The different port selection perspectives of trunk liners and feeder operators are analyzed by Chang et al. (2008) considering the Europe-East Asia and Intra-Asia trade routes. The advancement and convenience of ports, physical and operational ability, and port charges are highly appreciated by trunk liners, whereas feeder operators focus on the operational conditions of shipping lines and marketability. Saeed and Aaby (2013) identify loading/discharging rates, handling charges, and service quality as the most significant factors for container terminal selection in Europe, whereas personal contacts, investments by shipping lines, and value-added activities are the least significant factors. Port choice and inland transport mode choice behaviors are analyzed simultaneously by Wu and Peng (2013) for the Pearl River Delta region, considering monetary costs, costs for port dwell time, and costs incurred for intangible factors as the main determinants. As per Gohomene et al. (2016), the results of an analysis of 
port choice in Africa indicate infrastructure, port draft, political stability, market size/ cargo volume, and the international network as the most important selection factors.

Salem and El-Sakty (2014) study the competitiveness of East Mediterranean ports, considering cost, information technology (IT), location, depth, berth availability, equipment, infrastructure, and other factors as selection criteria. Zarei (2015) highlights the quality of products supplied by chandlers, advanced port management, infrastructure, and quality of suppliers' services as the main factors for port selection. According to Dyck and Ismael (2015), port efficiency and performance, political stability, cargo volume, location, costs, and infrastructure are important criteria for port selection in West Africa. Additionally, in evaluating the competitiveness of ports in the West African region, George and Hawa (2015) reveal that cargo volume, location, efficiency and performance, infrastructure, costs, and political stability are significant criteria. Kim et al. (2016) determine regional gateway port status by taking into account competitiveness in a multipolar port system in Northeast Asia, and they emphasize port availability, operational efficiency, port costs, and service quality as the primary factors. Ergin et al. (2015) indicate that port charges are the most important criterion, while the length of port berthing time and access to an electronic data interchange system are the least important criteria for port selection.

In addition, it is important to understand the perspectives of freight forwarders and shippers in port selection. The port selection criteria of shippers are determined by Chinonye et al. (2006) for Nigerian ports, and efficiency, frequency of ship visits, and adequate infrastructure are found to be significant. Grosso and Monteiro (2008) study the port selection criteria of freight forwarders in the port of Genoa, identifying port connectivity, cost and productivity, electronic information, and logistics as a few main criteria. To address competitiveness, Aronietis et al. (2010) use cost, capacity, hinterland connection, reliability, location, flexibility, and other evaluation criteria for Western European ports. The port selections of shippers and forwarders are analyzed by Langen (2007), who focuses on Australia and highlights that shippers and forwarders have similar views, although shippers indicate less price-elastic demand.

Beyond the literature on port selection, some case studies relate to port competition. Lam and Yap (2007) highlight that Kelang and Tanjung Pelepas provide competition for Singapore, although Singapore has continuously maintained the premier transshipment hub position. Ishii et al. (2013) study the competition between Busan and Kobe ports with game theory and analyze the significance of port charges and capacities. The competitive dynamics among East Asian container ports are analyzed by Yap and Lam (2006), who examine the long-run relationships with co-integration tests.

The reviewed literature reveals the various criteria from previous studies, and the findings differ based on decision maker perspectives. However, criteria such as cost and location are highlighted by most existing studies. Recent studies (i.e., Zarei (2015) and Wu and Peng (2013)) consider a different range of criteria, including qualitative factors, rather than confining their scopes primarily to cost. The majority of studies focus on the competitiveness of neighboring hub ports while analyzing competition in general despite the various liner network types. There are few studies on hub ports and feeder markets related to South Asia, and this visible knowledge gap in the literature emphasizes the significance of the current study. 


\section{Methodology}

\section{Study area selection}

This study focuses on evaluating the competitiveness of the ports of Colombo, Singapore, Kelang, and Tanjung Pelepas, which compete for transshipment traffic in the Bay of Bengal. Although the port of Colombo is located within the East-West main sea route as the major transshipment hub port in South Asia, Southeast Asian hub ports currently develop transshipment market shares even in South Asian feeder ports.

Therefore, to analyze competitiveness, these four ports were selected, and the geographical locations of the hub ports and the related study area are indicated in Fig. 2. The study considers both hub and spoke, and relay networks, so the feeder market around the Bay of Bengal is considered for hub and spoke networks, whereas relay networks are considered in general. The liner services operating along the East-West trunk sea route are considered for both cases.

To understand the current competitive situation among these hub ports in the Bay of Bengal feeder market, preliminary data analysis was conducted considering two factors, the "number of common services" and the "annual slot capacities (ASC) of common services," as illustrated in Figs. 3 and 4, respectively, with container shipping services data from 2013 provided by MDS Transmodel Inc 2013. These two factors were used individually as they can describe the transshipment volume of ports according to simple linear regression analysis carried out considering 38 container ports ("number of services" indicates an adjusted $\mathrm{R}$ square of 0.7434 and a $p$-value of 0.000 , and "ASC" indicates an adjusted $\mathrm{R}$ square of 0.7468 and a $p$-value of 0.000$)$. These 38 container ports were selected covering all ports in the world for which the ratio of transshipment TEUs to local cargo TEUs is greater than 0.5. The results of preliminary data analysis indicate that Singapore and Kelang are highly competitive for most feeder ports and that Colombo is considerably competitive as well. Tanjung Pelepas may be a potential competitor in the future even though it had the weakest performance. However, the relative competitiveness of the four hub ports is difficult to judge with only this preliminary data analysis, as all four ports play major roles as transshipment hub ports in liner

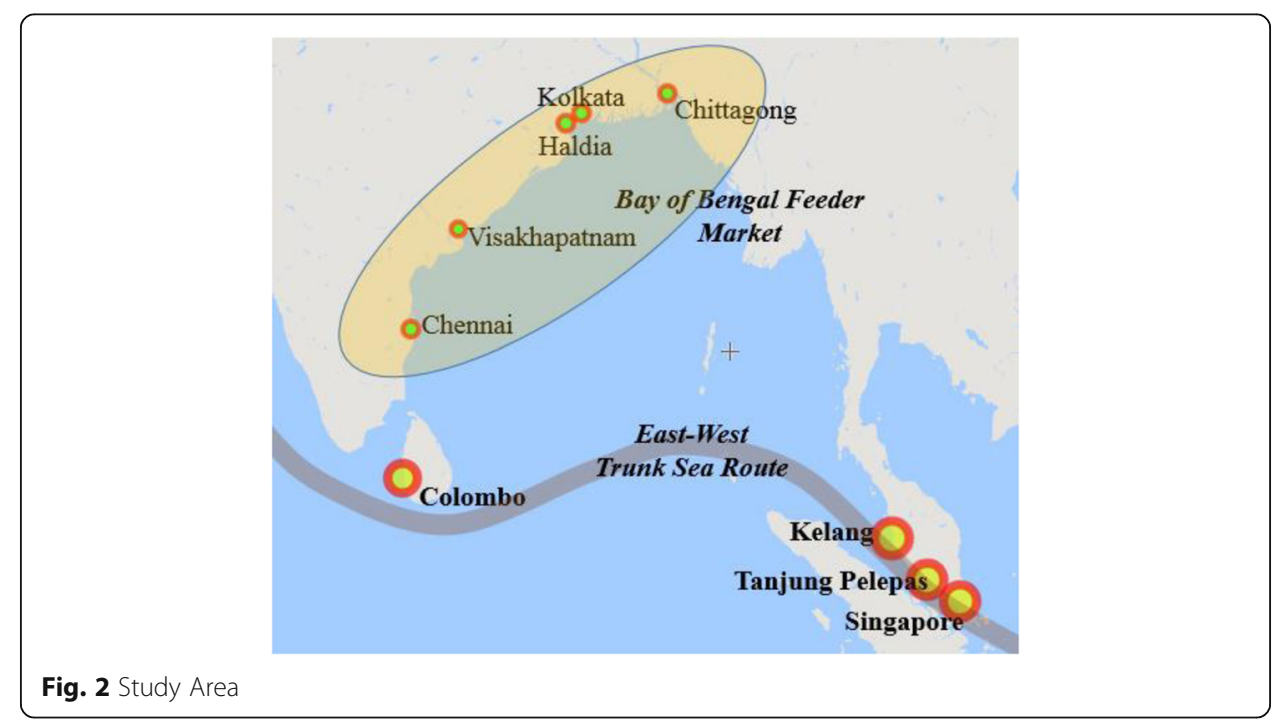




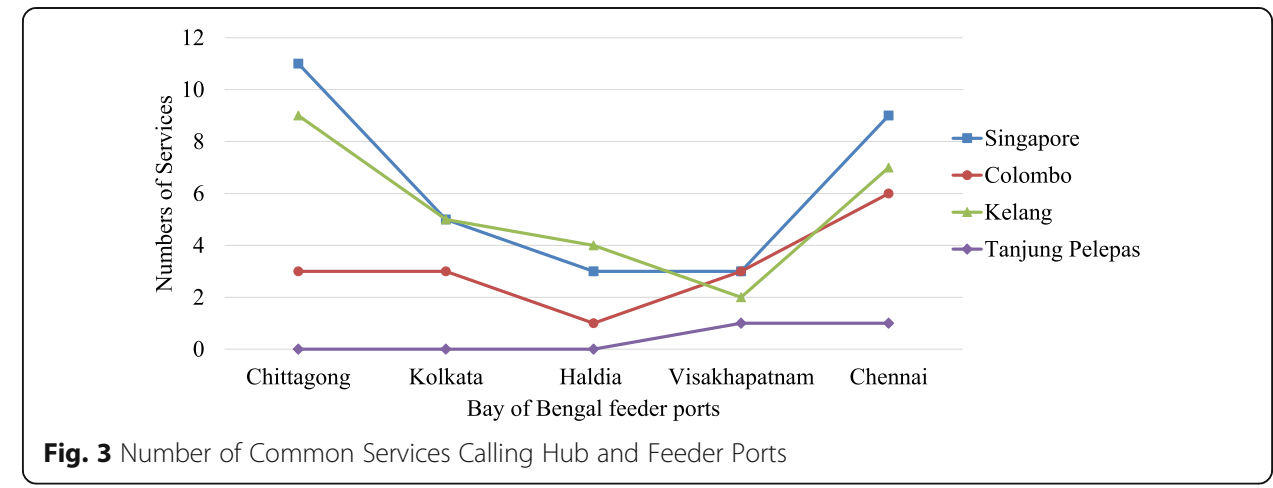

networks, as indicated by the considerably high percentages of transshipment TEUs relative to total port throughput (Singapore: 84\%; Colombo: 80\%; Kelang: 62\%; Tanjung Pelepas: 92\%) in 2013. Furthermore, all of these ports can accommodate larger-capacity vessels, as their drafts are over $16 \mathrm{~m}$ in length and their locations deviate less from the trunk sea route.

\section{Developing the contextualized framework of major influences on hub port selection}

In order to understand the relationships among the major influences on the hub port selection, a contextualized framework is developed from a practical viewpoint. This objective is accomplished by analyzing the qualitative data gathered during interviews with decision makers related to hub port selection as well as through questionnaire surveys of these decision makers. Our sample of decision makers covers twelve mainline companies and one feeder line company, as mentioned in Additional file 1. Interviews were conducted with experts from the network planning divisions of shipping lines and shipping associations in Singapore and Japan as well as with the port authority in Sri Lanka from September to December 2016. Singapore was selected for conducting interviews mainly because shipping lines' regional offices tend to be located in Singapore and because the employees of regional offices have more knowledge of and experience with hub port selection issues than representatives from local country offices. The practical procedures of liner service design, hub port selection criteria, and hub port competition issues are mainly discussed, in Additional file 1. The collected qualitative data were analyzed using the grounded theory approach (Bowyer and Davis 2012), which is a qualitative data analysis technique to develop a contextualized framework utilizing a

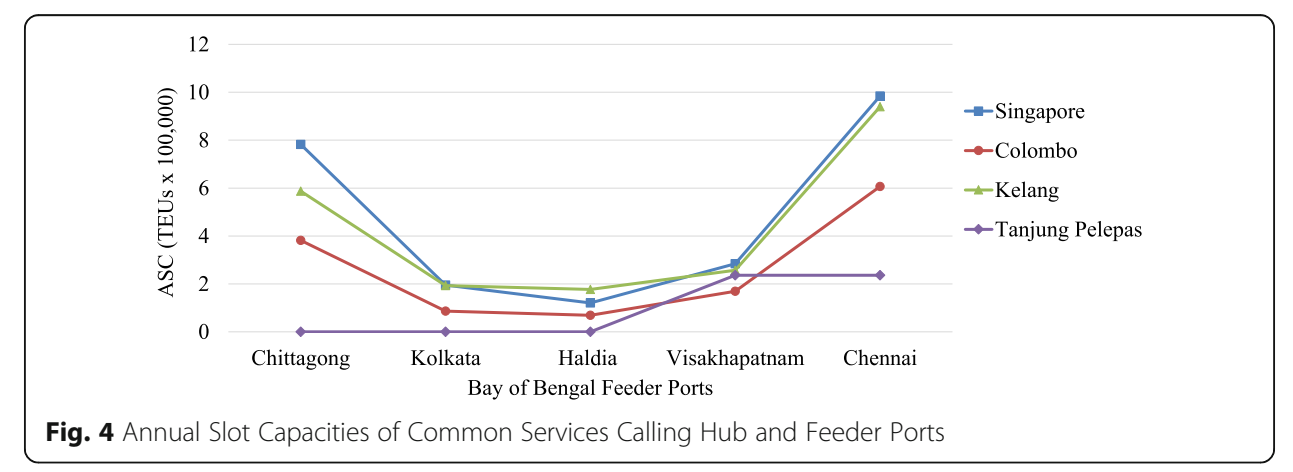


hyper-research analysis tool. The basic text coding related to grounded theory is explained in Table 1.

First, information from interviews was open coded, assigning different codes to each important piece of information and considering practical implications to generate fairly abstract categories with less restrictive thinking. Second, axial coding related open codes to each other, utilizing both inductive and deductive thinking to create meaningful categories. Finally, selective coding created a story by choosing a single category as a core category that could be related to all of the other categories.

\section{Identifying and categorizing hub port selection criteria and evaluating criteria significance}

Hub port selection criteria were mainly identified through the literature review, and, thereafter, certain non-related criteria were excluded from the list. For example, since the study focuses on transshipment hub port selection, criteria that are only related to seaport selection by shippers/consignees were excluded. New criteria were included to consider the practical aspects of liner businesses and network configurations. Subsequently, the identified criteria, especially the newly added criteria, were further discussed and verified during interviews.

After identification, the criteria were categorized based on their nature. Since most existing studies focused on the "monetary," "time," "location," and "operation" factors, as per Section 2, these four categories were initially identified. Additionally, the "port traffic" category was included based on its significance for hub port selection, and the "liner-related" category was included based on the relevant criteria for shipping lines, as discussed during the interviews. This study focuses on evaluating the significance of all the individual criteria and understanding how hub port performance relates to the criteria mentioned within all of the categories except the monetary category. As a result of the grouping process, three criteria fell under "monetary," four under "time," three under "port traffic," three under "location," fifteen under "operation," and six under "liner-related," as explained in following sub-sections with descriptions of the individual categories and criteria.

\section{Monetary category}

This category consists of the main criteria directly related to the costs incurred by shipping lines in the transshipment process, as described in Table 2.

Table 1 Grounded Theory Approach

\begin{tabular}{ll}
\hline Step & Description \\
\hline Open Coding & $\begin{array}{l}\text { The process of identifying, naming, and describing phenomena in } \\
\text { an abstract manner. }\end{array}$ \\
Axial Coding & The process of relating codes to each other by incorporating inductive \\
& and deductive thinking. \\
Selective Coding & The process of choosing one core category and relating all other \\
& categories to this category to develop a single framework through \\
& which everything else is related. \\
\hline
\end{tabular}


Table 2 Criteria Related to the Monetary Category

\begin{tabular}{ll}
\hline Criteria & Description \\
\hline Deviation cost & The journey cost incurred by shipping lines when deviating from the main \\
& sea route (i.e., the East West trunk sea route in the current study) to access \\
& hub ports. \\
Port cost & The monetary cost associated with operations at the hub port. This cost includes \\
& container handling charges; port dues, such as navigation dues; pilotage; towage; \\
& and so on. \\
Cost in feeder link & The cost associated with transporting cargo between hub and feeder ports. \\
& This criterion is relevant only for hub and spoke networks. \\
\hline
\end{tabular}

\section{Time category}

The main time-related criteria of the transshipment process are described in this category, as shown in Table 3. The levels of significance of the criteria could differ based on shipping lines' perceptions although these criteria may have similar characteristics. As an example, one shipping line may place a higher significance on the waiting time than on the deviation time, as the waiting time has a higher opportunity cost because the vessel is idle. Another shipping line, by contrast, may view the deviation time as more significant than the waiting time due to the high journey cost associated with deviation. Although some of these criteria are interrelated with some criteria in the monetary category (e.g., deviation time with deviation cost), the levels of significance given by shipping lines for time criteria could differ from those given for monetary cost criteria.

\section{Port traffic category}

Given the significance of port traffic in the hub port selection process, this category includes criteria directly related to the hub port's traffic, as explained in Table 4.

\section{Location category}

This category includes the criteria related to the locations of hub ports, as described in Table 5. Location is significant, as shipping lines attempt to maintain limited numbers of ports of call with maximum market coverage.

\section{Operation category}

This category consists of a range of operations-related criteria, shown in Table 6, that are significant for the hub port selection process, as shipping lines expect high operational performance from the hub port.

Table 3 Criteria Related to the Time Category

\begin{tabular}{ll}
\hline Criteria & Description \\
\hline Deviation time & The time taken to access a hub port after deviating from the trunk sea route. \\
Vessel turnaround time & The total time a vessel spends in port for the entire operation. \\
Waiting time & $\begin{array}{l}\text { The amount of time that vessels have to wait at the anchorage area before } \\
\text { entering the port. }\end{array}$ \\
Time in feeder link & $\begin{array}{l}\text { The time taken for transporting cargo between hub and feeder ports. This } \\
\text { criterion is relevant only for hub and spoke networks. }\end{array}$ \\
\hline
\end{tabular}


Table 4 Criteria Related to the Port Traffic Category

\begin{tabular}{ll}
\hline Criteria & Description \\
\hline $\begin{array}{l}\text { Availability of captive } \\
\text { cargo }\end{array}$ & This term refers to the availability of import/export cargo from the hub port's \\
hinterland, which helps to maintain high load factors for vessels. \\
$\begin{array}{l}\text { Frequency of ship } \\
\text { visits }\end{array}$ \\
$\begin{array}{l}\text { No. of services calling } \\
\text { at port }\end{array}$ & $\begin{array}{l}\text { The hub port connectivity in maritime networks. } \\
\text { hub port. }\end{array}$ \\
\hline
\end{tabular}

\section{Liner-related category}

This category describes the criteria related to shipping lines, as shown in Table 7, which can greatly influence hub port selection. These criteria are influenced by characteristics of shipping lines in addition to the characteristics of hub ports, while some of them seem to be partially interrelated with criteria in other categories.

After criteria identification and categorization, the significance of the criteria and performance of hub ports were evaluated with the questionnaire survey, and 13 respondents were selected from major shipping lines using the snowballing sampling method (Additional file 1). The sample represents about $60 \%$ of the world liner shipping market share and $75 \%$ of the transshipment market share in the South Asian feeder market, according to data provided by MDS Transmodal Inc. A pilot survey was conducted with one shipping line in Japan and one in Singapore, and their comments were used to improve the questionnaire survey. In-person discussions were conducted and respondents were provided with appropriate instructions. All respondents were at the senior management level of the operational/network planning divisions of shipping lines.

The questionnaire comprises three different sections. The first section was designed to gather general information about respondents, the representative company, designations, and so on. The second section evaluated the significance of each hub port selection criterion for both networks separately, as indicated in Additional file 1 . As proposed by Koi (2006), a significance score with a scale ranging from 0 (not significant) to 5 (highly significant) was used to evaluate the hub port selection criteria. Moreover, statistical tests were conducted to identify significant differences between the two networks in terms of individual categories as well as individual criteria. To describe the significance of the criteria, the average significance score (AvSS) of each individual criterion was calculated considering the average of the significance scores from the entire sample.

Table 5 Criteria Related to the Location Category

\begin{tabular}{ll}
\hline Criteria & Description \\
\hline $\begin{array}{l}\text { Location relative to other hub } \\
\text { ports }\end{array}$ & $\begin{array}{l}\text { Important aspects of the location of the hub port relative to those of other } \\
\text { competitive hub ports, such as whether hub ports are located in close } \\
\text { proximity to each other, market growth in the hub port region, and so on. }\end{array}$ \\
Accessibility of hub port & $\begin{array}{l}\text { Factors influencing the accessibility of hub ports, such as tides, water draft, } \\
\text { and so on. }\end{array}$ \\
Connected feeder markets & $\begin{array}{l}\text { The nature of the connected feeder market, such as whether the feeder market } \\
\text { has high growth potential and the cargo volume from the feeder market. This } \\
\text { criterion is relevant only for hub and spoke networks. }\end{array}$
\end{tabular}


Table 6 Criteria Related to the Operation Category

\begin{tabular}{|c|c|}
\hline Criteria & Description \\
\hline Port capacity & The overall capacity of the hub port from the viewpoint of shipping lines. \\
\hline Berth availability & $\begin{array}{l}\text { Berth availability based on the shipping line's experience (opportunities } \\
\text { for on-arrival berths, berthing windows, etc.). }\end{array}$ \\
\hline Frequency of delays & $\begin{array}{l}\text { The frequency of delays at the hub port, which increases the shipping line's } \\
\text { dissatisfaction, as liner shipping services are operated with pre-defined time } \\
\text { schedules. }\end{array}$ \\
\hline Records of damages & The occurrence of damage at hub ports from the shipping line's experience. \\
\hline $\begin{array}{l}\text { Port authority/custom } \\
\text { policies/regulations }\end{array}$ & $\begin{array}{l}\text { The nature of the business-friendly environment at the hub port and whether } \\
\text { there are very complex and time-consuming procedures/documentation and } \\
\text { regulations. }\end{array}$ \\
\hline Port infrastructure & The availability of adequate and advanced port infrastructure. \\
\hline Port superstructure & The availability of adequate and advanced facilities for vessel/cargo handling. \\
\hline IT and advanced technology & $\begin{array}{l}\text { The availability of advanced IT systems and related technology that enhance } \\
\text { convenience for shipping lines. }\end{array}$ \\
\hline Logistics facilities & $\begin{array}{l}\text { The capability of providing advanced logistics facilities for multi-country } \\
\text { consolidations, warehousing, and so on, which are essential for a transshipment } \\
\text { hub port. }\end{array}$ \\
\hline $\begin{array}{l}\text { Efficiency of navigational } \\
\text { services }\end{array}$ & $\begin{array}{l}\text { The efficiency of navigational services, such as pilotage, towage, and so on, } \\
\text { which are significant due to the large numbers of vessel movements and } \\
\text { larger vessel sizes at a hub port. }\end{array}$ \\
\hline $\begin{array}{l}\text { Efficiency of husbandry } \\
\text { services }\end{array}$ & $\begin{array}{l}\text { The efficiency of various husbandry services, such as ship repairs, bunkering, } \\
\text { and so on, at the hub port. }\end{array}$ \\
\hline Professional employees & $\begin{array}{l}\text { The presence of professional employees, which enhances convenience for } \\
\text { shipping lines when doing business. }\end{array}$ \\
\hline Marketing efforts & $\begin{array}{l}\text { Marketing efforts, including effective port pricing, incentives, and long-term } \\
\text { business relationships. }\end{array}$ \\
\hline $\begin{array}{l}\text { Port flexibility to shipping line } \\
\text { requests }\end{array}$ & $\begin{array}{l}\text { Flexibility in dealing with shipping lines' special requests, operational changes, } \\
\text { additional requirements, and so on, which could be important due to large } \\
\text { handling volumes at hub ports. }\end{array}$ \\
\hline Financial clearance capability & $\begin{array}{l}\text { The capability to provide financial clearance without inefficient and } \\
\text { complicated clearance processes, financial settlement durations, and so on. }\end{array}$ \\
\hline
\end{tabular}

\section{Evaluating the performances of hub ports}

From the third section of the questionnaire, the hub port performances related to the criteria grouped within the time, port traffic, location, operation, and liner-related categories were evaluated using the appreciation score proposed by Koi (2006), which uses a scale ranging from -3 (worst) to +3 (best). Respondents were requested to assign appropriate appreciation scores based on their experiences, as per the example in Additional file 1. To indicate the levels of performances of competitive hub ports in terms of individual criteria, the average appreciation scores (AvAS) of hub ports were calculated for each criterion considering the average of the appreciation scores from the entire sample. Although some of these criteria could be evaluated with real quantitative data, the perceptions of shipping lines, the main users of port facilities, are a significant factor to consider. The results of this analysis may be more meaningful than results using quantitative values, such as vessel turnaround times; waiting times, which differ based on the average size of a vessel; handling volumes; berthing windows; and so on.

After evaluation, the performances among hub ports were compared in terms of individual categories and criteria, and differences in statistical significance were tested using analysis of variance (ANOVA). 
Table 7 Criteria Related to the Liner-Related Category

\begin{tabular}{|c|c|}
\hline Criteria & Description \\
\hline $\begin{array}{l}\text { Availability of dedicated/own } \\
\text { terminal }\end{array}$ & $\begin{array}{l}\text { This criterion could be important given the contemporary nature of } \\
\text { the liner shipping industry, as many ports currently facilitate dedicated } \\
\text { terminals for shipping lines and shipping lines also invest in/develop } \\
\text { their own terminals at major ports. }\end{array}$ \\
\hline Personal contacts & $\begin{array}{l}\text { Since the maritime industry is characterized by strong networks of } \\
\text { relationships among business players, personal contacts tend to } \\
\text { be important. }\end{array}$ \\
\hline Special preferences on shipping lines & $\begin{array}{l}\text { This criterion refers to the special preferences on shipping lines, such as } \\
\text { incentives, favorable berthing windows, on-arrival berths, and so on. }\end{array}$ \\
\hline Availability of feeder services & $\begin{array}{l}\text { The high availability of feeder services is an essential component in hub } \\
\text { and spoke networks. Some shipping lines can have their own feeder } \\
\text { services serving hub ports. }\end{array}$ \\
\hline $\begin{array}{l}\text { Opinion/preferences of shipper/ } \\
\text { forwarder }\end{array}$ & $\begin{array}{l}\text { A shipping line's hub port selection decision could be influenced by the } \\
\text { opinions/preferences of that shipping line's own customers, such as } \\
\text { shippers, forwarders, and so on. }\end{array}$ \\
\hline $\begin{array}{l}\text { Position of hub port with shipping } \\
\text { line's services }\end{array}$ & $\begin{array}{l}\text { The position of a hub port relative to a shipping line's own services, the } \\
\text { proximity of the port to the next/previous hub ports with the same } \\
\text { available service, the availability of alternative hub ports in the same } \\
\text { region, and so on are all important. }\end{array}$ \\
\hline
\end{tabular}

\section{Developing the port performance index}

The port performance index (PPI) is one of the important elements of this analysis, as it reflects the overall performance of hub ports. The PPI incorporates both the significance levels of individual criteria, as reflected by their AvSSs, and the performances of individual hub ports evaluated with AvASs, as expressed by Eq. (1).

$$
\begin{aligned}
& \operatorname{PPI}(\mathrm{h})=\frac{\left[\sum_{\mathrm{i}=1}^{\mathrm{i}=\mathrm{n}} \operatorname{AvAS}_{(\mathrm{h}, \mathrm{TE}, \mathrm{i})} * \operatorname{AvSS}_{(\mathrm{TE}, \mathrm{i})}\right]}{\mathrm{n}}+\frac{\left[\sum_{\mathrm{i}=1}^{\mathrm{i}=\mathrm{n}} \operatorname{AvAS}_{(\mathrm{h}, \mathrm{PTE}, \mathrm{i})} * \operatorname{AvSS}_{(\mathrm{PTE}, \mathrm{i})}\right]}{\mathrm{n}} \\
& +\frac{\left[\sum_{\mathrm{i}=1}^{\mathrm{i}=\mathrm{n}} \operatorname{AvAS}_{(\mathrm{h}, \mathrm{LE}, \mathrm{i})} * \operatorname{AvSS}_{(\mathrm{LE}, \mathrm{i})}\right]}{\mathrm{n}}+\frac{\left[\sum_{\mathrm{i}=1}^{\mathrm{i}=\mathrm{n}} \operatorname{AvAS}_{(\mathrm{h}, \mathrm{OE}, \mathrm{i})} * \operatorname{AvSS}_{(\mathrm{OE}, \mathrm{i})}\right]}{\mathrm{n}} \\
& +\frac{\left[\sum_{\mathrm{i}=1}^{\mathrm{i}=\mathrm{n}} \operatorname{AvAS}_{(\mathrm{h}, \mathrm{LRE}, \mathrm{i})} * \operatorname{AvSS}_{(\mathrm{LRE}, \mathrm{i})}\right]}{\mathrm{n}} \\
& \text { n }
\end{aligned}
$$

where TE, PTE, LE, OE, and LRE refer to time, port traffic, location, operation, and liner-related efficiencies, respectively, and $i$ indicates the individual criteria discussed under each category. For example, $\operatorname{AvAS}_{(\mathrm{h}, \mathrm{TE}, \mathrm{i})}$ indicates the average appreciation score of hub port $h$ for the $i^{\text {th }}$ criterion in the time category, and $\operatorname{AvSS}_{(\mathrm{TE}}$, i) indicates the average significance score of the $\mathrm{i}^{\text {th }}$ criterion in the time category. Furthermore, $n$ indicates the number of criteria within each category. The PPI can be used to compare hub port performances since it incorporates both the significance of the criteria and the performances of the hub ports. A higher PPI indicates that a hub port is more competitive, as it results from having a comparatively higher AvAS than those of other hub ports even if the ports have equal AvSSs for each criterion. 


\section{Results and discussion}

\section{Contextualized framework of major influences on hub port selection}

The grounded theory approach was used for analyzing the qualitative data to develop the contextualized framework illustrated in Fig. 5. The framework is not related to any pre-defined theories but is based on the qualitative data collected through interviews.

According to Fig. 5, the five main influences on hub port selection were identified as "macro level factors," "strategic changes in the liner shipping industry," "port-related factors," "stakeholder influence," and "liner service design factors". The sub-factors related to each of these main factors are described in the following subsections.

\section{Macro level factors}

Here, both market and geographical factors are discussed. First, the role of the hub port's location as both a production and consumption center is significant to ensure the balance of trade movements (import/export) and realize low container reposition costs. Moreover, the number of connected markets and the presence of hub ports in multiple supply/value chains are both significant since main hub ports, such as Singapore, have a competitive advantage due to their attractive connected markets. As geographical influences, overlapping origin and/or destination markets could be served simultaneously by multiple hub ports. Therefore, the locations of the origin/destination markets are highlighted considering the high voyage costs.

\section{Strategic changes in the liner shipping industry}

Modifications of the operating structure from standalone services to liner alliances are significant. According to the interviews, services operated by alliances have high cargo demand and multiple strings due to the integration of several shipping lines. Therefore, different ports of call are maintained for different strings while prioritizing the preferences of individual alliance members. Liner investment in port infrastructure was highlighted since shipping lines currently invest in port infrastructure/terminals in addition to acting as pure container carriers. These investments are bound to create conflicts of interest, especially when selecting ports of call for services operated as

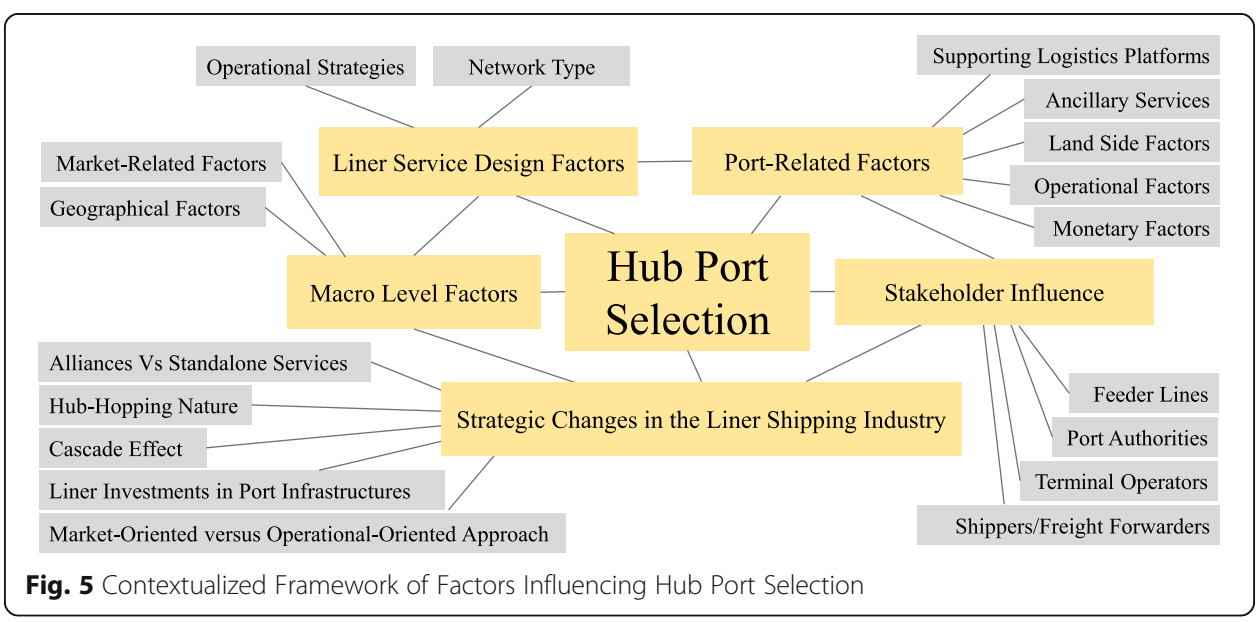


alliances, as the shipping lines in the alliance have various special preferences for their own terminals.

According to the interviews, a cascade effect characterized by the replacement of small vessels with large container carriers creates complexity, as shipping lines attempt to maintain limited ports of call due to high vessel operating costs and port infrastructure limitations. As such, both market-oriented and operational-oriented approaches in liner service design were discussed. As examples, shipping lines currently maintain multiple hub ports simultaneously to expand market coverage, thus incorporating the market-oriented approach. On the other hand, some major shipping lines relocate their transshipment hubs from existing major hub ports to newly developed ports due to advantages such as low cost and congestion free operations, as per the operationaloriented approach.

\section{Port-related factors}

In terms of the cost aspects of ports, container handling charges were considered to be significant, as they represent the major portion of port costs. The cost of husbandry services, however, was not deemed to be significant according to the interviews. Operational factors, such as handling efficiency, damages, flexibility and capacity, were highlighted, since poor performances of these factors reduce the attractiveness of a hub port despite low handling charges. In the case of a relay network, shipping lines expect special requirements, such as concurrent loading/unloading facilities between vessels and minimum inter-terminal transfers.

Excellent performances related to ancillary services (e.g., bunkering services and concurrent ship repair facilities with cargo handling) were identified as significant since mainline vessels are not willing to use additional ports just to receive ancillary services. Moreover, supporting logistics facilities (e.g., reefer facilities and multi-country consolidations) were considered significant. Finally, land side aspects were highlighted, since improved accessibility from the land side and inland cargo catchment areas enhances the attractiveness of hub ports, as shipping lines expect to receive not only transshipments but also captive cargo.

\section{Stakeholder influence}

The influences of several stakeholders are important for a shipping line's hub port selection decision, as discussed during interviews. Feeder carriers were considered to be significant since the availability of efficient feeder links is essential for cargo movements between the ultimate origins and destinations in hub and spoke networks. Depending on whether mainlines use their own or third party common feeder carriers, the hub port selection decision can be affected by the shipping lines' preference for hub ports with highly connected feeder services. According to the interviews, terminal operators are important since the negotiations on handing volumes mainly take place between terminal operators and shipping lines. The influence of mega-terminal operators was also highlighted due to large marketing and promotion efforts as well as the high bargaining power resulting from the terminal availability in multiple hub ports.

As per the interviews, port authorities play an important influencing role since they are responsible for managing not only the infrastructure and facilities but also the 
regulations and some commercial aspects of a port. Whether terminals are privately or publicly owned also influences hub port selection decisions. However, private terminals are preferred by most interviewees due to their efficient operations. Moreover, the preferences of shippers/forwarders were significant because shippers/forwarders prefer to choose hub ports with high feeder connectivity and excellent logistics facilities. However, all of these findings related to the contextualized framework are solely based on the results of an interview survey and consider perceptions from a practical perspective rather than a theoretical one, which is a limitation of this study.

\section{Liner service design factors}

Among liner service design factors, operational strategies such as service frequency, number of ports of call, and number of strings, are discussed as significant. Shipping lines attempt to maintain network simplicity, with limited ports of call, considering the overall cost aspects of the entire service network. As an example, maintaining a single hub port to cover multiple neighboring regions could be cost effective, but it requires multiple feeder links. However, some shipping lines select ports not called by many other services to create and expand their cargo bases. As previously discussed, shipping lines with competitive advantages, such as the availability of a strong cargo base, and those with their own feeder services can experience high autonomy in hub port selection decisions. Moreover, the possibilities of obtaining berth windows, on-arrival berths, virtual terminal agreements, and so on are highlighted as important attractive features. Regarding network types, interviews revealed that, although hub and spoke networks dominate, shipping lines currently focus on relay networks as well due to the opportunities of deploying their own mainline vessels. However, a relay network cannot be used independently in many cases without counting on feeder lines due to the capacity limitations of minor ports.

\section{Significance of hub port selection criteria}

Hub port selection criteria were evaluated for both networks to understand the significance of categories as well as that of the individual criteria. First, to determine the significance of each category, category-wise analysis was conducted for both network types considering the average of the significance scores of all criteria in the same category. The significance scores of all six categories were compared between the two networks using t-tests over the entire sample. Table 8 indicates statistically significant differences only for the category of time-related criteria, for which hub and spoke networks have a higher mean score. The interviews indicated conflicting opinions. The majority of interviewees mentioned that time performance is highly important for hub and spoke networks due to the high frequency of undertaking hub and spoke network-

Table 8 Comparisons of the Significance of Categories between Hub and Spoke and Relay

\begin{tabular}{lllllll}
\hline Category & Monetary & Time & Port Traffic & Location & Operation & Liner-related \\
\hline Hub and Spoke & 4.54 & 4.67 & 3.87 & 4.13 & 4.00 & 3.44 \\
Relay & 4.31 & 4.40 & 3.79 & 4.12 & 3.90 & 3.31 \\
t-stat & 0.847 & $\mathbf{1 . 9 2 3 *}$ & 0.674 & 0.102 & 1.227 & 0.875 \\
\hline
\end{tabular}

Note: *represents significance at the $5 \%$ level 
related transshipments and the high cost associated with the feeder segment, usually operated by a third-party feeder operator, which requires greater time efficiency. However, according to few interviewees, relay networks demand high performances on time-related criteria since both transshipment vessels are operated by mainline services, which requires delivering promised service levels with fixed time schedules and predefined ports of call.

The remaining five categories do not exhibit statistically significant differences. According to the interviews, despite the distinct characteristics of the network types, some shipping lines tend to use the same hub port for both network types due to the high bargaining power associated with large handling volumes. Moreover, shipping lines have special preferences for different ports/terminals and generally try to minimize the number of ports of call. It is reasonable to find no significant difference between the two network types in the monetary category as, even for the feeder segment of a hub and spoke network, the port handling charges are paid by mainlines rather than feeder operators, as per the interviews.

After comparing the significances of the categories between the two networks, comparisons between each possible pair of categories within the same network type were performed to identify the important categories for each network, as indicated in Table 9. For hub and spoke networks, all the category pairs indicate statistically significant differences except for "Monetary-Time," "Port Traffic-Location," "Port Traffic-Operation," and "Location-Operation." The significant differences between most of the pairs imply

Table 9 Comparisons of Significance of Categories within the Same Network Type

\begin{tabular}{|c|c|c|c|}
\hline & & Hub and Spoke & Relay \\
\hline \multirow[t]{6}{*}{ Mean Score } & Monetary & 4.54 & 4.31 \\
\hline & Time & 4.67 & 4.40 \\
\hline & Port Traffic & 3.87 & 3.79 \\
\hline & Location & 4.13 & 4.12 \\
\hline & Operation & 4.00 & 3.90 \\
\hline & Liner-related & 3.44 & 3.31 \\
\hline \multirow[t]{15}{*}{ Pair of Categories t-stat } & Monetary-Time & -0.948 & -0.570 \\
\hline & Monetary-Port Traffic & $3.225^{*}$ & 1.228 \\
\hline & Monetary-Location & $2.259^{*}$ & 0.732 \\
\hline & Monetary-Operation & $3.648^{*}$ & 1.320 \\
\hline & Monetary-Liner-related & $5.977^{*}$ & $2.309 *$ \\
\hline & Time-Port Traffic & $4.485^{*}$ & $2.249 *$ \\
\hline & Time-Location & $3.220^{*}$ & 1.752 \\
\hline & Time-Operation & $5.100^{*}$ & $2.745^{*}$ \\
\hline & Time-Liner-related & $9.860^{*}$ & $3.665^{*}$ \\
\hline & Port Traffic-Location & -1.443 & -1.244 \\
\hline & Port Traffic-Operation & -1.224 & -0.617 \\
\hline & Port Traffic-Liner-related & $2.029^{*}$ & $1.965^{*}$ \\
\hline & Location-Operation & 0.874 & 1.250 \\
\hline & Location-Liner-related & $2.902^{*}$ & $2.806^{*}$ \\
\hline & Operation-Liner-related & 3.093* & $2.508^{*}$ \\
\hline
\end{tabular}


that shipping lines' expectations vary by category. The port traffic, location, operation, and liner-related categories obtained significantly lower mean scores than did the monetary category, emphasizing the high significance of the monetary category. This finding is reasonable, as minimizing the overall cost is a major concern due to high feeder costs in hub and spoke networks. Moreover, the time category obtained a significantly higher mean score than did the port traffic, location, operation, and liner-related categories, whereas the port traffic, location, and operation categories obtained significantly higher mean scores than did the liner-related category. According to the interviews, shipping lines consider the time and monetary categories to be more significant since these factors are generally out of shipping lines' control, whereas many liner-related criteria can be controlled by shipping line strategies.

For relay networks, seven pairs of categories, namely, "Monetary-Liner-related," "Time-Port Traffic," “Time-Operation," "Time-Liner-related," "Port Traffic-Linerrelated," "Location-Liner-related," and "Operation-Liner-related," obtained significant differences. The results indicate that, for shipping lines, the significance levels of different categories vary less in the relay case as compared to the hub and spoke case. However, for the relay case, only the liner-related category has a significantly lower mean score than the monetary category. This result implies that shipping lines are not significantly prioritizing the monetary category, possibly due to the lower cost in the relay case given the absence of the feeder segment. The relay case has a significantly higher mean score for the time category than for the port traffic, operation, and liner-related categories, whereas the port traffic, location, and operation categories obtain significantly higher mean scores than that of the liner-related category. The liner-related category is not considered significant in the relay case, especially because of high flexibility, as both transshipment vessels come from their own mainline services. For both networks, the mean scores of the time category are slightly higher than those for the monetary category, even though the differences are not statistically significant.

Although the category-wise comparison provides abstract evidence on the significance of individual categories, a detailed discussion on the significance of each individual criterion is essential to create effective contributions. The AvSSs of each criterion for both networks are obtained as per Table 10, indicating the level of importance of each criterion calculated as the average significance score from the entire sample. Only five criteria, "hub port accessibility," "frequency of delays," "records of damages," "efficiency of husbandry services," and "availability of dedicated/own terminal," obtained a higher AvSS in the relay case than in the hub and spoke case. Since the relay case involves transshipment between two mainline vessels with larger dimensions, assigning high AvSSs for hub port accessibility is reasonable. According to the interviews, performance with minimal delays and damages is expected, as both mainline vessels are operated with fixed time schedules and pre-defined ports of call. Since mainline vessels do not call in additional ports to receive husbandry services, it is reasonable to consider the efficiency of husbandry services highly significant for relay networks. Similarly, the high significance of the availability of a dedicated/own terminal in relay networks is reasonable since both vessels are from mainline services.

"Port superstructures," "port flexibility," "financial clearance capability," and "number of services calling at port" obtained equal AvSSs for both networks. Therefore, these 
Table 10 Average Significance Scores (AvSSs) of the Criteria

\begin{tabular}{|c|c|c|c|}
\hline Criteria & Hub and Spoke & Relay & t-stat \\
\hline Deviation Cost & 4.46 & 4.31 & 0.413 \\
\hline Port Cost & 4.46 & 4.31 & 0.562 \\
\hline Cost in Feeder Link & 4.69 & N/A & N/A \\
\hline Deviation Time & 4.69 & 4.31 & 0.938 \\
\hline Vessel Turnaround Time & 4.77 & 4.54 & $1.915^{*}$ \\
\hline Waiting Time & 4.46 & 4.31 & 1.000 \\
\hline Time in Feeder Link & 4.77 & N/A & N/A \\
\hline Availability of Captive Cargo & 3.77 & 3.62 & 0.485 \\
\hline Frequency of Ship Visits & 3.92 & 3.85 & 0.562 \\
\hline Number of Services Calling at Port & 3.92 & 3.92 & 0.000 \\
\hline Location Relative to Other Hub Ports & 4.00 & 3.85 & 1.477 \\
\hline Hub Port Accessibility & 4.23 & 4.39 & -0.616 \\
\hline Connected Feeder Markets & 4.15 & N/A & N/A \\
\hline Port Capacity & 4.31 & 4.23 & 0.562 \\
\hline Berth Availability & 5.00 & 4.85 & 1.477 \\
\hline Frequency of Delays & 4.69 & 4.77 & -1.000 \\
\hline Records of Damages & 3.69 & 3.62 & -0.322 \\
\hline Port Authority/Customs Policies/Regulations & 4.00 & 3.85 & 1.000 \\
\hline Port Infrastructure & 4.15 & 4.08 & 0.562 \\
\hline Port Superstructure & 3.92 & 3.92 & 0.000 \\
\hline IT and Advanced Technology & 4.00 & 3.69 & 1.298 \\
\hline Logistics Facilities & 4.08 & 3.62 & $2.144^{*}$ \\
\hline Efficiency of Navigational Services & 4.31 & 4.08 & 1.389 \\
\hline Efficiency of Husbandry Services & 3.00 & 3.15 & -0.805 \\
\hline Professional Employees & 4.00 & 3.92 & 1.000 \\
\hline Marketing Efforts & 3.23 & 3.00 & 1.389 \\
\hline Port Flexibility on Shipping Line Requests & 4.15 & 4.15 & 0.000 \\
\hline Financial Clearance Capability & 3.62 & 3.62 & 0.000 \\
\hline Availability of Dedicated/Own Terminal & 3.08 & 3.23 & -0.805 \\
\hline Personal Contacts & 3.23 & 3.15 & 1.000 \\
\hline Special Preferences on Shipping Lines & 3.23 & 3.00 & $1.897^{*}$ \\
\hline Availability of Feeder Services & 3.77 & N/A & N/A \\
\hline Opinions/Preferences of Shippers and Forwarders & 3.62 & 3.54 & 0.322 \\
\hline Position of Hub Port with Shipping Line Services & 3.69 & 3.62 & 0.562 \\
\hline
\end{tabular}

Note: * represents significance at the $5 \%$ level. Underlined criteria indicate the highest AvSS for both networks, italic criteria indicate higher AvSS for relay networks than for hub and spoke networks, and bold criteria indicate equal AvSS for both networks

criteria can be considered as general prerequisites for a transshipment hub port regardless of the network type. Hub and spoke networks obtained higher AvSSs for most criteria relative to the relay case. According to Ducruet and Notteboom (2012), 85\% of transshipments are currently related to hub and spoke networks, whereas only $15 \%$ are associated with relay networks. Therefore, high AvSSs could possibly be attributed to hub and spoke networks. "Berth availability" obtained the highest AvSS for both networks, possibly because shipping lines appreciate on-arrival berths due to high port 
congestion. Commercial aspects, such as marketing efforts and special preferences, were assigned the least importance irrespective of network type, which was also highlighted during the interviews.

The results of the statistical tests in the third column of Table 10 indicate statistically significant differences between the two networks for three criteria, namely "vessel turnaround time," "logistics facilities," and "special preferences on shipping lines." The high significance for vessel turnaround time in the hub and spoke case could be due to the high numbers of loading/unloading containers from the large volume of transshipments, which eventually lead to a high turnaround time. Similarly, both logistics facilities and special preferences on shipping lines could be considered more significant in the hub and spoke case, especially due to the lack of advanced value-adding facilities in feeder ports. However, considering the ranking of criteria in individual networks, criteria related to the feeder segment are prioritized in the hub and spoke case possibly due to the high feeder cost, as per interviews, and criteria related to time, deviation, and accessibility are prioritized in the relay case.

\section{Performance of hub ports}

Hub port performances were evaluated considering each criterion mentioned under the time, port traffic, location, operation, and liner-related categories. First, for the comparisons of port performances by category, the averages of the appreciation scores across all criteria within the same category were calculated for each hub port and were compared for each possible port pair using a t-test, as in Table 11. In terms of the time category, Singapore has a significantly higher performance than those of the other three hub ports, possibly because it has the least deviation from the main sea route and advanced port operation technology, which eventually contributes better time-related performance. In the port traffic category, Singapore again has a significantly higher performance than those of the other three hub ports, and Colombo has a significantly higher performance than that of Tanjung Pelepas. As highlighted by Albert and Olli-Pekka (2012), Singapore has several competitive advantages to justify its transshipment hub position, mainly due to its extensive connectivity around the world and the high frequencies of these connections. In terms of the location category, Colombo has

Table 11 Category-Wise Performance Comparison among Hub Ports

\begin{tabular}{lllllll}
\hline Categories & & Time & Port Traffic & Location & Operation & Liner-related \\
\hline Mean Score & Singapore & 2.12 & 2.10 & 2.33 & 2.14 & 1.68 \\
& Colombo & 1.52 & 1.18 & 2.00 & 1.07 & 1.14 \\
& Kelang & 1.33 & 1.18 & 1.38 & 1.16 & 0.91 \\
& Tanjung Pelepas & 1.15 & 0.85 & 1.23 & 0.95 & 0.87 \\
Port Pair t-stat & Singapore- Colombo & 2.934 & $\mathbf{3 . 3 5 5 ^ { * }}$ & 0.941 & $\mathbf{4 . 7 7 7 ^ { * }}$ & $\mathbf{2 . 0 6 4 ^ { * }}$ \\
& Singapore - Kelang & 4.652 & $\mathbf{3 . 6 4 0 ^ { * }}$ & $\mathbf{3 . 6 3 4}^{*}$ & $\mathbf{5 . 4 0 6}^{*}$ & $\mathbf{4 . 4 6 0 ^ { * }}$ \\
& Singapore - Tanjung Pelepas & 4.911 & $\mathbf{4 . 7 0 1 *}$ & $\mathbf{3 . 4 3 4}^{*}$ & $\mathbf{4 . 9 8 0 ^ { * }}$ & $\mathbf{3 . 6 3 2 ^ { * }}$ \\
& Colombo - Kelang & 1.130 & 0.000 & 1.730 & -0.488 & 1.220 \\
& Colombo - Tanjung Pelepas & 1.594 & $\mathbf{1 . 8 4 2}$ & $\mathbf{2 . 2 0 6 ^ { * }}$ & 0.626 & 1.065 \\
& Kelang - Tanjung Pelepas & 1.028 & 1.732 & 1.066 & 1.448 & 0.220 \\
\hline
\end{tabular}

Note: *represents significance at the $5 \%$ level 
a significantly higher performance than that of Tanjung Pelepas. Singapore also has a significantly higher performance than those of Kelang and Tanjung Pelepas. These results are reasonable, since Colombo has advantages mainly related to its location within the feeder market. However, since the location category includes three criteria, Singapore has more advantages in terms of the remaining two location-related criteria (i.e., hub port accessibility and location relative to other hub ports) than other three hub ports have.

For both the operation and liner-related categories, Singapore has a significantly higher performance than those of the other three hub ports. As discussed during the interviews, shipping lines highly appreciate the performance of Singapore due to combinations of several factors, including high operation efficiency, convenience, and advanced and automated technology. Additionally, shipping lines are appreciative of Singapore's efficient repair facilities, as unavailable spare parts are immediately imported by air, and repairs are made while loading/unloading. Moreover, due to sufficient capacity, Singapore can handle the entire volumes of major shipping lines with high flexibility for customer requests given its excellent operating performance. The pairs of the other three ports, excluding Singapore, do not indicate significant differences, and these ports may have lower performances for some criteria in the operation and liner-related categories, which will be discussed in later sections of this paper.

Hub port performances related to individual criteria were analyzed using AvAS. AvAS was calculated as the average appreciation score across the entire sample for each individual criterion. The first five columns of Table 12 indicate the criteria and the AvASs of the four hub ports, and the sixth column shows the results of the ANOVA tests. The calculated AvASs reveal the dominant performance of Singapore for most criteria with the exception of the "time in feeder link" and the "connected feeder markets" criteria, for which Colombo's performance is superior. Tanjung Pelepas has the lowest performance for most criteria.

Singapore has significantly high performances for criteria in the port traffic category, specifically, "frequency of ship visits" and "number of services calling at port," as reflected by its almost 18,000 vessel arrivals in 2016 and its connections in maritime networks with 600 ports globally. Other hub ports have comparatively lower connectivity levels than Singapore has. Singapore performs significantly better than Colombo and Tanjung Pelepas, especially for operational criteria such as "port infrastructure," "port superstructure," "IT and advanced technology," and "logistics facilities," as Singapore has over 200 quay cranes, more than 60 container berths, and almost 20,000 m of quay length, whereas Colombo and Tanjung Pelepas have fewer than 60 quay cranes, fewer than 15 container berths, and less than $6000 \mathrm{~m}$ of quay length. Moreover, Singapore has over 40 million TEU capacity, whereas Tanjung Pelepas has only 10.5 million TEU capacity.

Colombo performs significantly better than Kelang and Tanjung Pelepas in terms of "connected feeder markets," as it is located in close proximity to Indian sub-continent feeder ports. Colombo has the lowest performances for seven different criteria, namely "deviation time," "records of damage," "policies and regulations," "IT and advanced technology," "marketing effort," "finance clearance capability," and "position of hub port with shipping line's services." Although Colombo is currently undergoing major 
Table 12 Average Appreciation Scores (AvAS) of Hub Ports

\begin{tabular}{|c|c|c|c|c|c|c|}
\hline Criteria & Singapore & Colombo & Kelang & $\begin{array}{l}\text { Tanjung } \\
\text { Pelepas }\end{array}$ & $\operatorname{Pr}(>\mathrm{F})$ & Remarks \\
\hline Deviation Time & 2.54 & 1.54 & 1.54 & 1.77 & $0.032^{*}$ & $\begin{array}{l}\text { Singapore > Colombo, Kelang, } \\
\text { Tanjung Pelepas }\end{array}$ \\
\hline Vessel Turnaround Time & 2.23 & 1.08 & 1.38 & 0.85 & $0.001^{* *}$ & $\begin{array}{l}\text { Singapore }>\text { Colombo, Kelang, } \\
\text { Tanjung Pelepas /Kelang > } \\
\text { Tanjung Pelepas }\end{array}$ \\
\hline Waiting Time & 2.46 & 1.31 & 1.15 & 1.08 & $0.006^{* *}$ & $\begin{array}{l}\text { Singapore > Colombo, Kelang, } \\
\text { Tanjung Pelepas }\end{array}$ \\
\hline Time in Feeder Link & 1.23 & 2.15 & 1.23 & 0.92 & $0.045^{*}$ & $\begin{array}{l}\text { Colombo > Singapore, Kelang, } \\
\text { Tanjung Pelepas }\end{array}$ \\
\hline $\begin{array}{l}\text { Availability of Captive } \\
\text { Cargo }\end{array}$ & 1.54 & 1.08 & 1.31 & 0.92 & 0.674 & \\
\hline Frequency of Ship Visits & 2.54 & 1.39 & 1.31 & 1.00 & $0.004^{* *}$ & $\begin{array}{l}\text { Singapore > Colombo, Kelang, } \\
\text { Tanjung Pelepas }\end{array}$ \\
\hline $\begin{array}{l}\text { Number of Services } \\
\text { Calling at Port }\end{array}$ & 2.23 & 1.08 & 0.92 & 0.62 & $0.000 * * *$ & $\begin{array}{l}\text { Singapore > Colombo, Kelang, } \\
\text { Tanjung Pelepas }\end{array}$ \\
\hline $\begin{array}{l}\text { Location Relative to } \\
\text { Other Hub Ports }\end{array}$ & 2.62 & 1.92 & 1.08 & 1.23 & $0.001 * *$ & $\begin{array}{l}\text { Singapore > Kelang, Tanjung } \\
\text { Pelepas }\end{array}$ \\
\hline Hub Port Accessibility & 2.69 & 1.69 & 1.62 & 1.54 & 0.077 & \\
\hline $\begin{array}{l}\text { Connected Feeder } \\
\text { Markets }\end{array}$ & 1.69 & 2.39 & 1.46 & 0.92 & $0.001^{* *}$ & $\begin{array}{l}\text { Colombo > Kelang, Tanjung } \\
\text { Pelepas }\end{array}$ \\
\hline Port Capacity & 2.54 & 1.69 & 1.39 & 1.08 & $0.024^{*}$ & Singapore > Tanjung Pelepas \\
\hline Berth Availability & 2.31 & 1.31 & 0.92 & 1.00 & $0.009^{* *}$ & $\begin{array}{l}\text { Singapore > Kelang, Tanjung } \\
\text { Pelepas }\end{array}$ \\
\hline Frequency of Delays & 1.85 & 0.77 & 0.54 & 0.62 & $0.009^{* *}$ & $\begin{array}{l}\text { Singapore > Kelang, Tanjung } \\
\text { Pelepas }\end{array}$ \\
\hline Records of Damages & 1.62 & 1.00 & 1.08 & 1.08 & 0.573 & \\
\hline Policies and Regulations & 2.00 & 0.85 & 1.23 & 0.92 & 0.082 & \\
\hline Port Infrastructure & 2.46 & 1.23 & 1.46 & 1.15 & $0.010^{*}$ & $\begin{array}{l}\text { Singapore > Colombo, } \\
\text { Tanjung Pelepas }\end{array}$ \\
\hline Port Superstructure & 2.39 & 1.23 & 1.31 & 1.00 & $0.010^{*}$ & $\begin{array}{l}\text { Singapore > Colombo, } \\
\text { Tanjung Pelepas }\end{array}$ \\
\hline $\begin{array}{l}\text { IT and Advanced } \\
\text { Technology }\end{array}$ & 2.31 & 0.85 & 1.39 & 1.08 & $0.011^{*}$ & $\begin{array}{l}\text { Singapore > Colombo, } \\
\text { Tanjung Pelepas }\end{array}$ \\
\hline Logistics Facilities & 2.62 & 1.31 & 1.46 & 1.08 & $0.009^{* *}$ & $\begin{array}{l}\text { Singapore > Colombo, } \\
\text { Tanjung Pelepas }\end{array}$ \\
\hline $\begin{array}{l}\text { Efficiency of Navigational } \\
\text { Services }\end{array}$ & 2.15 & 1.31 & 1.46 & 1.08 & 0.107 & \\
\hline $\begin{array}{l}\text { Efficiency of Husbandry } \\
\text { Services }\end{array}$ & 2.39 & 0.85 & 1.15 & 0.62 & 0.107 & \\
\hline Professional Employees & 2.15 & 1.15 & 1.23 & 1.00 & $0.047^{*}$ & Singapore > Tanjung Pelepas \\
\hline Marketing Efforts & 1.77 & 0.85 & 1.08 & 1.08 & 0.235 & \\
\hline Port Flexibility & 1.69 & 0.85 & 0.62 & 0.69 & 0.163 & \\
\hline $\begin{array}{l}\text { Financial Clearance } \\
\text { Capability }\end{array}$ & 1.92 & 0.77 & 1.08 & 0.77 & $0.029^{*}$ & $\begin{array}{l}\text { Singapore > Colombo, } \\
\text { Tanjung Pelepas }\end{array}$ \\
\hline $\begin{array}{l}\text { Availability of Dedicated/ } \\
\text { Own Terminal }\end{array}$ & 1.15 & 1.08 & 0.85 & 1.08 & 0.938 & \\
\hline
\end{tabular}


Table 12 Average Appreciation Scores (AvAS) of Hub Ports (Continued)

\begin{tabular}{|c|c|c|c|c|c|c|}
\hline Criteria & Singapore & Colombo & Kelang & $\begin{array}{l}\text { Tanjung } \\
\text { Pelepas }\end{array}$ & $\operatorname{Pr}(>F)$ & Remarks \\
\hline Personal Contacts & 1.62 & 1.00 & 0.77 & 0.69 & 0.064 & \\
\hline $\begin{array}{l}\text { Special Preferences of } \\
\text { Shipping Lines }\end{array}$ & 1.08 & 0.85 & 0.77 & 0.77 & 0.88 & \\
\hline $\begin{array}{l}\text { Availability of Feeder } \\
\text { Services }\end{array}$ & 2.62 & 1.92 & 1.31 & 1.15 & $0.002^{* *}$ & $\begin{array}{l}\text { Singapore > Kelang, Tanjung } \\
\text { Pelepas }\end{array}$ \\
\hline $\begin{array}{l}\text { Opinions/Preferences of } \\
\text { Shippers and Forwarders }\end{array}$ & 2.08 & 1.23 & 0.77 & 0.77 & $0.008^{* *}$ & $\begin{array}{l}\text { Singapore > Kelang, Tanjung } \\
\text { Pelepas }\end{array}$ \\
\hline $\begin{array}{l}\text { Position of Hub Port with } \\
\text { Shipping Line's Services }\end{array}$ & 1.54 & 0.77 & 1.00 & 0.77 & 0.29 & \\
\hline
\end{tabular}

infrastructure development, the lower performance of Colombo cannot be completely addressed with only infrastructure development. In particular, criteria such as policy and regulations and financial clearance capability must be considered by port authorities since they are strategic responsibilities. Moreover, since the availability of IT and advanced technologies indicates a lower performance, IT should be improved to enhance competitiveness.

For Kelang, eight criteria, namely "deviation time," "location relative to other hub ports," "berth availability," "frequency of delays," "port flexibility," "availability of dedicated/own terminals," "special preferences on shipping lines," and "opinions/preferences of shippers and forwarders," indicate the lowest performances. As discussed during the interviews, shipping lines experience congestion, delays, and comparatively fewer opportunities to have dedicated/liner-own terminals in Kelang. Therefore, those operation and liner-related criteria are significant for maintaining the competitiveness of Kelang as a hub port. Additionally, since Tanjung Pelepas has the lowest performances for most criteria, consideration by port authority and terminal operators is essential. According to the interviews, although Tanjung Pelepas is located strategically on the East-West main route, some shipping lines are not willing to choose Tanjung Pelepas because its port capacity and operational efficiency are not sufficient to handle the entire cargo volume of shipping lines.

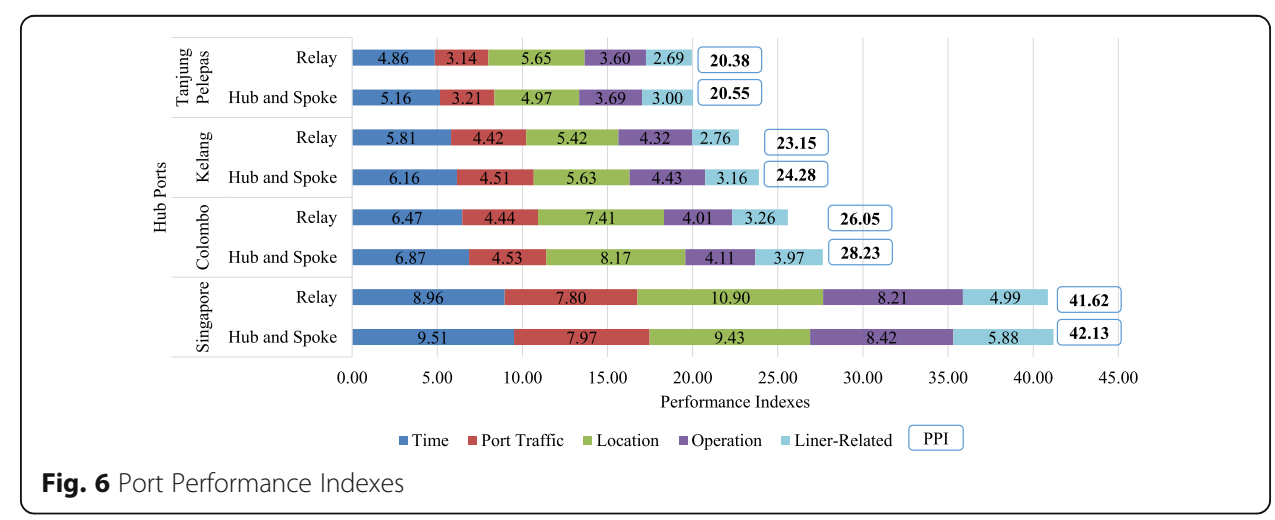




\section{Port performance index}

The PPI is calculated using Eq. (1) to indicate the performance of each hub port, as shown in Fig. 6. The PPI incorporates the previously calculated AvSS and AvAS scores. Singapore obtained the highest PPI, whereas Tanjung Pelepas obtained the lowest PPI for both networks. Colombo has a considerably lower PPI for the relay case than for the hub and spoke case, whereas Tanjung Pelepas indicates almost similar PPIs for both network types. The higher PPIs of all hub ports for hub and spoke networks than for relay networks could be a result of the higher AvSSs of most criteria in the hub and spoke case than in the relay case. This finding implies the high attractiveness of these hub ports as transshipment hub ports in hub and spoke networks. Singapore's PPI is significantly higher than those of the other three hub ports. Therefore, regardless of the high handling cost, shipping lines call at Singapore because it guarantees operational performance, as per the previous experiences of shipping lines. According to shipping lines, although Singapore can replace Colombo, Kelang, and Tanjung Pelepas in liner services for both networks, none of these ports can replace Singapore. Especially in relay networks, shipping lines appreciates the strategies of Singapore, such as virtual terminal agreements, on arrival berths.

All hub ports have advantages in terms of time and location categories, which are the main influencers of the PPI, whereas the PPIs of Singapore and Tanjung Pelepas for relay networks are highly influenced by the location category, which could be due to the absence of feeder-link-related criteria. The liner-related category has the least influence on the PPI for all hub ports in both networks. Furthermore, the comparatively lower performances in the liner-related and time categories may contribute to the low PPIs of both Kelang and Tanjung Pelepas in the relay case. The influences of both the port traffic and operation categories are nearly the same for all hub ports, although Singapore has a slightly higher contribution from the operation category.

Colombo has a considerably lower PPI for the relay case, mainly due to the absence of criteria related to the feeder segment in relay networks, because these feeder-linkrelated criteria generate competitive advantages for Colombo. However, the PPIs of Colombo and Singapore are significantly different even in the hub and spoke case. For instance, even though Colombo is located close to South Asian feeder ports, shipping lines may use Singapore as a hub with a higher feeder cost because it can generate lower overall network costs than when using both Singapore and Colombo. The significantly lower PPI of Tanjung Pelepas could mainly be a result of shipping lines' perceptions of Tanjung Pelepas as a newly emerging hub port, as mentioned during interviews, and this PPI value may change in the future. The worst-performing criteria related to each hub port should be addressed to increase the PPIs of individual hub ports, and ports should focus on their high-performing criteria as competitive advantages.

\section{Conclusion}

The transshipment hub port selection decision is critical for shipping lines, since the process involves determining a range of criteria, and for port service providers, since these decisions directly influence their business opportunities. From the port operator perspective, competitive pressure has increased the challenges in creating and maintaining customer satisfaction. Therefore, knowing the exact requirements of shipping 
lines is significant to fine tune businesses in a competitive manner. As such, this study identifies the significance criteria for the transshipment hub port selection of shipping lines for both hub and spoke and relay networks.

Although there were differences in the transshipment hub port selection criteria between the two networks, "berth availability" was selected as the most significant criterion for both networks. For hub and spoke networks, high significance was given to criteria associated with the feeder segment, whereas criteria such as hub port accessibility and frequency of delays were considered significant for relay networks. Commercial aspects, such as marketing efforts, personal contacts, and other aspects, were identified as least significant for both networks. Since only the time category significantly differed between the two networks, hub port selection may not have clear distinctions between the two networks from the shipping lines' perspective despite the different network configurations of hub and spoke and relay.

According to the performance evaluations of hub ports around the Bay of Bengal, the dominant performance of Singapore was highlighted for most criteria, whereas the performances of the other hub ports varied by criteria. Tanjung Pelepas had the lowest performance for most criteria, and Colombo and Kelang also had the lowest performances on few criteria. Therefore, recommendations could be made for each port to enhance competitiveness. This study has its limitations. Although respondents at senior management levels from relevant divisions of shipping lines were selected to ensure representativeness, methods other than surveys can be considered, to avoid the influence of respondents' subjectivity. As further research, new criteria can be added considering the developed contextualized framework (e.g., macro level factors), and nonsignificant criteria can be excluded.

\section{Additional file}

Additional file 1: Table S1. Sample for the Study. Table S2. Main Areas Discussed During the Questionnaire Survey. Table S3. Evaluating Hub Port Selection Criteria. Table S4. Evaluating the Performances of Competitive Hub Ports. Table S5. List of Abbreviations. (DOCX 76 kb)

Acknowledgements

Not applicable

Funding

This work was supported by JSPS KAKENHI Grant Number $17 \mathrm{H} 03327$.

Availability of data and materials

Not applicable

Authors' contributions

Authors contributed jointly to the manuscript. All authors read and approved the final manuscript.

Competing interests

The authors declare that they have no competing interests.

\section{Publisher's Note}

Springer Nature remains neutral with regard to jurisdictional claims in published maps and institutional affiliations.

\section{Author details}

${ }^{1}$ Department of Transdisciplinary Science and Engineering, Tokyo Institute of Technology, Tokyo, Japan. ${ }^{2}$ Department of Transdisciplinary Science and Engineering, Tokyo Institute of Technology, Tokyo, Japan. ${ }^{3}$ Department of Transdisciplinary Science and Engineering, Tokyo Institute of Technology, Tokyo, Japan. ${ }^{4}$ Japan Maritime Center, Tokyo, Japan. 
Received: 26 January 2018 Accepted: 2 April 2018

\section{Published online: 20 April 2018}

\section{References}

Albert WKT, Olli-Pekka H (2012) Future of transshipment in Singapore. Ind Manag Data Syst 112(7):1085-1100 Aronietis R, Voorde EV, Vanelslander T (2010) Port competitiveness determinants of selected European ports in the containerized cargo market. In: Paper presented at the annual conference of the International Association of Maritime Economists, Lisbon, Portugal, 7-9 July 2010

Bowyer D, Davis G (2012) How to acquire aircraft? A grounded theory approach to case study research. Qual Res Account Manag 9(4):363-397

Chang Y, Lee S, Jose LT (2008) Port selection factors by shipping lines: different perspectives between trunk liners and feeder service providers. Mar Policy 32:877-885

Chinonye U, Ogochukwu U, Innocent CO (2006) An analytic hierarchy process (AHP) approach to port selection decisions-empirical evidence from Nigerian ports. Mar Econ Log 8:251-266

Ducruet C, Notteboom T (2012) Developing liner service networks, in Container shipping, maritime logistics: a complete guide to effective shipping and port management. Kogan page, pp 77-100

Ducruet C, Sung-Woo L, Adolf KYN (2011) Port Competition and Network Polarization in the East Asian Maritime Corridor, Territoire en mouvement Revue de géographie et aménagement [En ligne], 10 | 2011, mis en ligne le 01 juin 2013, consulté le 20 septembre 2017. URL: http://journals.openedition.org/tem/1327; DOI: https://doi.org/10. 4000/tem.1327

Dyck GKV, Ismael HM (2015) Multi-criteria evaluation of port competitiveness in West Africa using analytic hierarchy process (AHP). Am J Indust Bus Manag 5:432-446

Ergin A, Eker I, Alkan G (2015) Selection of container port using ELECTRE technique. International journal of operations and. Logist Manag 4(4):268-275

George KVD, Hawa MI (2015) Multi-criteria evaluation of port competitiveness in West Africa using analytic hierarchy process (AHP). Am J Indust Bus Manag 5:432-446

Gohomene DA, Yang ZL, Bonsal S, Maistralis E, Wang J, Li KX (2016) The attractiveness of ports in West Africa: some lessons from shipping lines' port selection. Growth Change 47(3):416-426

Grosso M, Monteiro F (2008) Relevant strategic criteria when choosing a container port -the case of the port of genoa. Assoc Eur Transport Contrib:1-21. https://www.scirp.org

Ishii M, Lee PT, Tezuka K, Chang Y (2013) A game theoretical analysis of port competition. Transp Res E 49:92-106

Kim S, Kang D, Dinwoodie J (2016) Competitiveness in a multipolar port system: striving for regional gateway status in Northeast Asia. Asian J Shipp Logist 32(2):119-126

Koi YAN (2006) Theory and structure of port competition, Dissertation. University of Oxford, The Oxford University Research Archive. https://ora.ox.ac.uk/objects/uuid:f3f91b0f-4c65-4664-8fba-87281e7e8ae5

Kurt I, Boulougouris E, Turan O (2015) An AHP decision support model for the hub port choice of the shipping liners on the Mediterranean region. In SCC2015- International Conference on Shipping In Changing Climates; 24-26 November 2015

Lam JSL, Yap WY (2007) Competition for transshipment containers by major, ports in Southeast Asia: slot capacity analysis. Paper presented at the International Conference on Logistics, Shipping and Port Management, 2007

Langen PW (2007) Port competition and selection in contestable hinterlands: the case of Austria. Eur J Transp Infrastruct Res 7(1):1-14

Lirn TC, Beynon MJ (2006) An application of AHP on transshipment port selection. Mar Econ Log 8:251-266

Lirn TC, Thanopoulou HA, Beresford AKC (2003) Transshipment port selection and decision-making behavior: analyzing the Taiwanese case. Int J Log Res Appl 6(4):229-244

MDS Transmodel Inc. MDS containership databank. (2013)

Minju B, Chew EP, Lee LH, Zhang A (2011) Container transshipment and port competition. National University of Singapore, Dissertation

Notteboom T, Parola F, Satta G (2014) State of the European Port System - Market Trends and Structure Update: Partim Transshipment Volumes, 7th Framework Programme SST.2013.6-2. In: Towards a competitive and resource efficient port transport system Collaborative Project

Saeed N, Aaby BC (2013) An analysis of factors contributing as selection criteria for users of European container terminals, Proceedings of the Transportation Research Board 92 Annual Meeting, January 13-17

Salem II, El-Sakty KG (2014) Port selection criteria and its impact on port competitiveness. Int J Human Soc Sci 3(6):29-36

Soamiely A, Hugh A, Michael JF (2004) Transshipment in the United States. U.S. International Trade Commission, Office of Economics, Washington

Tai H, Hwang C (2005) Analysis of hub port choice for container trunk lines in East Asia. J Eastern Asia Soc Transp Stud 6:907-919

Veldman SJ, Buckmann EH (2003) A model on container port competition: an application for the west European container hub-ports. Mar Econ Log 5:3-22

Wang $L$ (2011) Container seaport selection criteria for shipping lines in a global supply chain perspective: implications for regional port competition. MSc in Maritime Economics and Logistics. Erasmus University Rotterdam. http://hdl. handle.net/2105/33114

Wu Y, Peng C (2013) A container port choice model for Pearl River Delta region in South China. Soc Behav Sci 96: 1839-1852

Yap WY, Lam JSL (2006) Competition dynamics between containers ports in East Asia. Transp Res A 40:35-51

Zarei S (2015) The key factors in shipping Company's port selection for providing their supplies. International journal of social, behavioral, educational, economic, business and. Ind Eng 9(4):1317-1321 